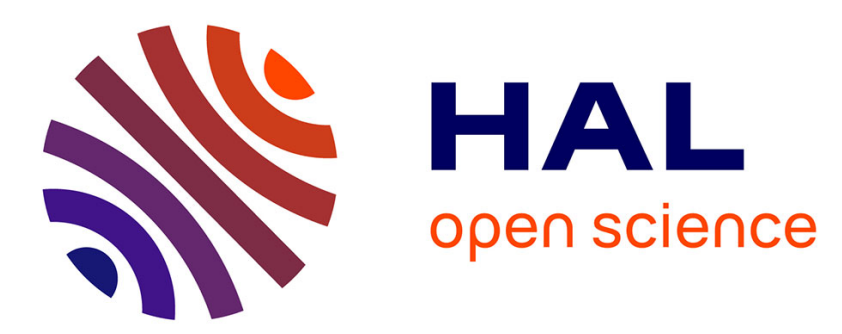

\title{
Genome analysis of Marinobacter phage AS1 suggests its close interactions with host Marinobacter sp
}

\author{
Sreekumar Aparna, Ammini Parvathi, Angia Sriram Pradeep Ram,
} Télesphore Sime-Ngando

\section{- To cite this version:}

Sreekumar Aparna, Ammini Parvathi, Angia Sriram Pradeep Ram, Télesphore Sime-Ngando. Genome analysis of Marinobacter phage AS1 suggests its close interactions with host Marinobacter sp. Aquatic Microbial Ecology, 2019. hal-03043263

\section{HAL Id: hal-03043263 https://hal.science/hal-03043263}

Submitted on 7 Dec 2020

HAL is a multi-disciplinary open access archive for the deposit and dissemination of scientific research documents, whether they are published or not. The documents may come from teaching and research institutions in France or abroad, or from public or private research centers.
L'archive ouverte pluridisciplinaire HAL, est destinée au dépôt et à la diffusion de documents scientifiques de niveau recherche, publiés ou non, émanant des établissements d'enseignement et de recherche français ou étrangers, des laboratoires publics ou privés. 
4

5

6

\title{
Genome analysis of Marinobacter phage AS1 suggests its close interactions with host
} Marinobacter sp.

\author{
Aparna S. ${ }^{1}$, Parvathi A. ${ }^{1 *}$, Pradeep Ram A. S. ${ }^{2}$ and Sime-Ngando T. ${ }^{2}$
}

${ }^{1}$ CSIR-National Institute of Oceanography, Regional Centre (CSIR), Kochi-682 018, India

${ }^{2}$ Laboratoire Microorganismes : Génome et Environnement, UMR CNRS 6023, Université ClermontAuvergne, 1 Impasse Amélie Murat, 63178 Aubière Cedex, France

\section{* Corresponding author}

2 Dr. Parvathi A.

3

CSIR-National Institute of Oceanography

Regional Centre, Dr. Salim Ali Road,

Post Box No. 1913, Kochi-682 018, India

Ph: 91-(0) 484-2390814, Fax: 91-(0) 484-2390618

Email: parvathi@nio.org

8

19

\section{Running title: Whole genome characterization of Marinobacter phage AS1}

1

2

23

4

5




\section{Abstract}

Marinobacter comprises a widespread and ecologically significant genus of marine bacteria

3 with vast metabolic capabilities. However, very few reports on phages infecting this genus exist. In

4 this study, we isolated and characterized a linear dsDNA genome of Marinobacter phage AS1, 5 infecting Marinobacter sp. strain, D1S9. The phage is a member of Podoviridae family having a 6 genome size of $\sim 37 \mathrm{~kb}$ and a $57 \%$ GC content with no significant overall similarity to any of the 7 available viral whole genome sequences in the database. The genome which encodes for 52 protein 8 coding genes with no tRNA genes, contains 21 protein coding genes with assigned putative functions. 9 High degree of recombination events with other members of the family Caudovirales is evident from 10 the mosaic pattern of inheritance of genes such as major capsid protein, terminase large sub unit, 11 portal protein and integrase. Presence of integrase gene, DNA methyl transferases and the occurrence 12 of $\mathrm{AS} 1$ sequences within the whole genome sequences of some members of the host taxon were 13 suggestive of its intense association with the host.

15 Keywords: Marinobacter, phage, complete genome sequence, Podovirus, Arabian Sea 


\section{Introduction}

Viruses, primarily bacteriophages are the most prolific and diverse obligate parasites in the marine biosphere where they outnumber bacteria on an average by one order of magnitude (Suttle,

4 2007, Sime-Ngando 2014). Bacteriophages have indispensable involvement in the ecological and 5 biogeochemical processes by regulating bacterial abundance, bacterial diversity, nutrient fluxes, 6 structuring the microbial food web dynamics and to a great extent in influencing host diversification 7 and speciation through horizontal gene transfer (Middelboe and Lyck, 2002, Bouvier and Del Giorgio 8 2007, McDaniel et al. 2010, Winget et al. 2011). A considerable fraction of bacterial genetic diversity 9 is acquired through horizontal gene transfer, imparting ecological and pathogenic attributes like 10 antibiotic resistance, resistance to phage infection, toxins and heavy metals (Stern and Sorek, 2010, 11 Xia and Wolz, 2014). Phage genomes are also coevolving concomitantly with their hosts. Compared 12 to other host-parasite systems, bacterial-phage coevolution is faster owing to their large population 13 sizes and short generation times (Buckling and Brockrust 2012). Studies with coevolving populations 14 of hosts and their infective phages revealed two modes of coevolution: arms race dynamics (ARD) 15 and fluctuating selection dynamics (FSD). These two were found to operate at different times in the 16 same population with arms race dynamics giving way to fluctuating selection dynamics in the long 17 run (Hall et al. 2011, Gokhale et al. 2013).

Most of the dsDNA phages share a large pool of genetic elements (Hendrix et al. 1999). 19 Phage genomes exhibit prevalent mosaic architecture as a result of extensive horizontal gene transfer 20 and in fact different genomic segments may have different ancestral origins. So, it is challenging to 21 deduce whole genome similarities and to assign phylogenetic relationships to newly sequenced 22 phages (Hatfull and Hendrix 2011). Isolation and genome characterization of additional phages would 23 help to resolve this problem to some extent. 
Despite of the profound knowledge on abundance and role of marine viruses in

biogeochemical cycles and host population dynamics, genome level information on phage-host interactions of ecologically significant bacteria are very limited. Sequencing and whole genome characterization of phages infecting these bacteria might provide insights into the phage-host interactions and how they shape the ecological roles of the hosts. Marinobacter, an ecologically significant genus of bacteria, and its first representative, M. hydrocarbanoclasticus, was proposed by Gauthier in 1992. Since then, new members belonging to this genus have been isolated from diverse marine habitats ranging from oil producing wells to deep-sea benthic sediments with fifty-eight species reported so far (Martin et al. 2003, Yoon et al. 2007, Xu et al. 2008, Zhang et al. 2008, Wang et al. 2009, Wang et al. 2012, Chua et al. 2018). Several species have been associated with marine sponges and microalgae (Green et al. 2006, Kaeppel et al. 2012, Lee et al. 2012, Lupette et al. 2016, Sandhya et al. 2017). Members of this genus are known to have substantial impact on marine snow formation and on various biogeochemical cycles with quite a few strains possessing a repertoire of activities like degradation of various hydrocarbon compounds, denitrification, Fe (II) oxidation, $\mathrm{Mn}$ (II) oxidation, Fe (III) reduction and redox cycling of arsenic and fumarate (Kaye et al. 2010, Kaeppel et al 2012, Wang et al. 2012, Handley and Lloyd 2013, Bonis and Gralnick 2015). Although their versatile functional capabilities enable them to survive in diverse environmental conditions and to exploit variable resources (Singer et al. 2011), viruses infecting this genus are reported rarely (Zhu et al. 2018), thus hindering an integrated understanding of the life cycle of these microbes in the marine environments. In this study, we report the isolation of a bacteriophage infecting the genus Marinobacter from surface waters of the Arabian Sea (southwest coast of India) and provide firsthand information on the sequencing and whole genome analysis of it. 
2. Materials and Methods

\subsection{Isolation and purification of Marinobacter phage AS1 and its host}

Marinobacter phage AS1 was isolated from the surface water of the tropical Arabian Sea, off the coast of Kochi, southwest coast of India $\left(9.9586^{\circ} \mathrm{N}\right.$ and $76.0825^{\circ}$ E, Fig. 1A) in December 2014

6 as described by Middelboe et al. (2010). Briefly, $25 \mathrm{~mL}$ water sample was amended with $1 \mathrm{~mL} \mathrm{10x}$

7 Zobell marine broth and incubated at room temperature for 2 days in order to propagate potential

8 bacterial hosts and thereby the specific viruses in the sample (Himedia, Mumbai, India). The viral 9 enriched seawater was screened against lawns of bacterial isolates obtained from the same water 10 sample by means of soft agar overlay technique. Culturing of bacteria was done by spread plating 11 water samples on Zobell Marine Agar. The plaques formed on the bacterial lawn after overnight 12 incubation $\left(37^{\circ} \mathrm{C}\right.$ ) were picked and transferred to phage buffer (SM buffer: $450 \mathrm{mM} \mathrm{NaCl}, 50 \mathrm{mM}$ $13 \mathrm{MgSO}_{4}, 50 \mathrm{mM}$ Tris, $0.01 \%$ gelatin, $\mathrm{pH} 8$ ), vortexed well and kept at $4^{\circ} \mathrm{C}$. Centrifugation $(10,000$ $14 \times \mathrm{g}, 10 \mathrm{~min}$ ) was done the next day to remove the soft agar and host cell remnants which was followed 15 by filtration through $0.2 \mu \mathrm{m}$ pore size Acrodisc syringe filters (Sigma-Aldrich, India). The filtrate was 16 then serially diluted and plated by soft agar overlay method. Single plaque from the plate was isolated 17 and the purification was repeated for five consecutive times. The phage stock was stored at $4{ }^{\circ} \mathrm{C}$ until 18 use.

The bacterial isolate for which the phage was isolated was identified using 16S rRNA gene 20 polymerase chain reaction (Amann et al. 1995). The PCR products were sequenced and identified by 21 BLAST search against non-redundant database of NCBI.

\section{2.2. Transmission Electron microscopy (TEM)}


For morphometric characterization of phage by TEM analysis, the purified phage particles

were collected onto 400-mesh carbon coated formvar grids by centrifugation $(70,000 \times \mathrm{g}, 20$ minutes at $\left.4^{\circ} \mathrm{C}\right)$ using a SW 40Ti rotor and stained at room temperature for $30 \mathrm{~s}$ with uranyl acetate stain $(2 \%$ w/v) (Pradeep Ram et al. 2010). Excess stain on grids was removed by rinsing twice with $0.02 \mu \mathrm{m}$ filtered distilled water and dried on filter paper. Grids were examined using a JEOL 1200Ex transmission electron microscope (JEOL, Akishima, Japan) operated at $80 \mathrm{kV}$ at a magnification between $\times 60,000$ and $\times 100,000$.

\subsection{Phage DNA isolation}

Phage particles were precipitated with $8 \%$ polyethylene glycol (PEG) 8000 containing $1 \mathrm{M}$ $\mathrm{NaCl}$ after overnight incubation at $4^{\circ} \mathrm{C}$ (Lawrence and Steward 2010). The mixture was centrifuged at $10000 \times g$ for $20 \mathrm{~min}$ at $4^{\circ} \mathrm{C}$ and the pellet was suspended in SM buffer to disaggregate overnight at $4^{\circ} \mathrm{C}$. To remove the $\mathrm{PEG}, \mathrm{KCl}$ was added to the viral suspension to a final concentration of $1 \mathrm{M}$ and kept on ice for $30 \mathrm{~min}$. PEG was pelleted by centrifugation at $12000 \times g$ for $10 \mathrm{~min}$ at $4{ }^{\circ} \mathrm{C}$ and the supernatant containing viral particles were transferred to a fresh tube. The viral suspension was concentrated using Amicon Ultra-15 centrifugal filter unit with a molecular weight cut off of $30 \mathrm{kDa}$ (Millipore, India). The concentrated phage preparation was treated with nucleases (DNase I and RNase $\mathrm{A}$ at final concentrations of $1 \mathrm{mg} \mathrm{mL}^{-1}$ ) to remove any host DNA and RNA. Phage DNA was extracted using the phenol:chloroform (24:1) extraction method as described previously (Yang et al. 2017). Briefly, the nuclease treated phage preparation was treated with proteinase $\mathrm{K}\left(100 \mathrm{mg} \mathrm{mL}^{-1}\right)$, $10 \%(\mathrm{w} / \mathrm{v})$, SDS and $0.5 \mathrm{M}$ EDTA $\left(\mathrm{pH}\right.$ 8) and incubated in water bath at $55{ }^{\circ} \mathrm{C}$ for $1 \mathrm{hr}$. This was followed by two rounds of phenol:chloroform:isoamyl alcohol $(25: 24: 1)$ extraction at 12,000 rpm at $4^{\circ} \mathrm{C}$ for $10 \mathrm{~min}$. Again, the aqueous phase was purified by chloroform:isoamyl alcohol (24:1) extraction at $12,000 \mathrm{rpm}$ at $4^{\circ} \mathrm{C}$ for $10 \mathrm{~min}$. The supernatant was mixed with isoamyl alcohol and 
1 incubated overnight at $-20{ }^{\circ} \mathrm{C}$. The pellet was washed with $70 \%$ ethanol and air dried. DNA was

2 resuspended in TE buffer (10 mM Tris-HCl, $1 \mathrm{mM}$ EDTA, $\mathrm{pH} 8.0)$ and stored at $4{ }^{\circ} \mathrm{C}$.

\subsection{Genome sequencing and bioinformatic analyses}

Whole genome sequencing library was prepared with Illumina-compatible NEXTflex rapid DNA sequencing kit (BIOO Scientific, Inc., USA) at Genotypic Technology Pvt. Ltd., Bangalore, India. 100 ng of Qubit quantified DNA was sheared using Covaris S220 sonicator (Covaris, Inc., USA) to generate specific fragments with size range of 300-400 bp. The fragment size distribution was verified on Agilent 2200 TapeStation and subsequently purified using HighPrep magnetic beads (MagBio Genomics, Inc., USA). Purified fragments were end-repaired, adenylated and ligated to

11 Illumina multiplex barcode adapters as per NEXTflex rapid DNA sequencing kit protocol. Illumina universal adapters used in the study are:

3' and Index Adapter: 5'-GATCGGAAGAGCACACGTCTGAACTCCAGTCAC [INDEX] ATCTCGTATGCCGTCTTCTGCTTG-3’.

17 for 5 cycles of PCR using Illumina-compatible primers provided in the NEXTflex rapid DNA 18 sequencing kit. Final PCR product (sequencing library) was purified with HighPrep beads, followed by library quality control. Sequencing library was quantified by Qubit fluorometer (Thermo Fisher Scientific, MA, USA) and its fragment size distribution was analyzed on Agilent 2200 TapeStation. The library was sequenced using Illumina MiSeq $(275 \times 2$ chemistry) platform. The Illumina

22 paired-end raw reads were quality checked using FastQC (Andrews 2010). The high-quality reads 23 were then assembled using SPAdes assembler (Bankevich et al. 2012). Gene calling and primary 
1 annotation of the assembled genome was done using the RAST server (Aziz et al. 2008). The proteins

2 thus predicted were similarity searched against Uniprot Virus and bacterial protein databases with an

3 E-value cut off of $<10^{-5}$. The conserved domains on proteins were identified using NCBI conserved

4 domain database (Marchler-Bauer et al. 2016). The tRNAs were predicted in the assembled genome

5 using tRNAscan-SE (Lowe and Chan 2016). ARNold12 was used for the identification of rho-

6 independent transcriptional terminators (Naville et al. 2011). The search procedure used two

7 complementary programs Erpin and RNAmotif. Potential promoter sequences and the trans-

8 membrane helices in the proteins were predicted using Martin Reese's Neural Network Promoter

9 Prediction (Reese 2001) and TMHMM2.014 server (http://www.cbs.dtu.dk/services/TMHMM/),

10 respectively. The SignalP 4.1 server (http://www.cbs.dtu.dk/services/SignalP/) was used to detect

11 presence and location of signal peptide in amino acid sequences. Phylogenetic trees were constructed

12 using MEGA version 7 (Kumar et al. 2016) by maximum likelihood method based on the LG+G+I

13 model with ClustalW aligned amino acid sequences of major capsid protein, phage portal protein,

14 terminase large subunit, major tail protein and integrase. Bootstrap values were based on 100

15 replications. Genome sequence of Marinobacter phage AS1 was deposited in GenBank database

16 under accession number, MK088078.

\section{3. Results and Discussion}

\section{3.1. Growth and morphometric characteristics of Marinobacter phage AS1}

The host, Marinobacer sp. strain D1S9 is a Gram negative, rod shaped bacterium (Fig 1B)

20 isolated from the surface waters of the Arabian Sea. The host present in the water sample was

21 enriched by the addition of nutrients which in turn amplified the specific viruses for the host. The

22 isolated phages formed clear, round plaques of 1-2 mm diameter with regular edges on lawns of the

23 host after 10-12 h of incubation (Fig 1C). Morphometric characteristics of phage AS1 examined by 
transmission electron microscopy analysis indicated it belonged to family Podoviridae of the order Caudovirales. The phage resembled morphotype $\mathrm{C} 1$ with an icosahedral head (isometric) having a capsid diameter of $\sim 50 \mathrm{~nm}$ (Bradley, 1967). With a presence of short, stubby, non-contractile tail, characteristic of this group (Fig. 2). Host range experiments with 9 laboratory isolates of Marinobacter did not result any infection, indicating its narrow host range.

\subsection{Genome features and annotation}

Illumina sequencing and assembly of AS1 genome generated a single contig with a coverage of $92.5 \%$. The assembled genome of Marinobacter phage AS1 was linear with a sequence length of $37 \mathrm{~kb}$ with a GC content of 57\% (Fig. 3). The general features of AS1 genome are listed in Table 1. An initial whole genome similarity search against the NCBI non-redundant database using basic local alignment search tool (BLAST) showed no close relatives to Marinobacter phage AS1. AS1 genome showed no significant similarity to any of the three already reported Marinobacter phages, PS3 (GenBank accession, MF959999), PS6 (GenBank accession, MF959998) or B23 (Zhu et al. 2018; GenBank accession, KY939598). However, the AS1 phage represents the first Marinobacter phage belonging to the family Podoviridae. When phage AS1 genome was searched against the whole genome shotgun sequences of the taxon Marinobacter (taxid: 2742) using NCBI- BLAST, it showed an identity of $96 \%$ with Marinobacter manganoxydans isolate UBA5690_contig_21412 (DIHS01000048) and $94 \%$ with Marinobacter sp. N4 KEHDKFFH_1 (PSSX01000001) with query coverages of $85 \%$ and $73 \%$ respectively. This observation indicates the existence of fragments of AS1 genome within Marinobacter population and its possible interactions with the hosts. A total of 52 protein coding genes were predicted in the genome, of which 21 have assigned putative functions (Table 2). Genes related to phage structure and assembly, DNA modification, transcriptional regulation and host cell lysis were arranged in distinct functional clusters along the genome (Table 3). 
1 The similar sequences of AS1 found within the genomes of $M$. manganoxydans isolate

2 UBA5690_contig_21412 (in reverse orientation) and Marinobacter sp. N4 KEHDKFFH_1 are

3 depicted in Fig. 4. They include genes encoding the small and large subunits of terminase, capsid

4 proteins, portal protein, tail proteins, integrase, transcriptional regulators, methyl transferase,

5 endonuclease, lysozyme and hypothetical proteins. Phage sequence was broken up and various

6 functional clusters were shuffled within a particular region of the bacterial genomes.

7 The structural and assembly module encodes both small and large subunits of terminase,

8 portal protein, serine peptidase, major capsid protein, Gp6, Gp3, major tail protein, tail fiber proteins

9 and tail tape measure protein. The terminase large subunit protein (Gene 2) contains a P-loop having

10 nucleoside triphosphate hydrolase activity and belongs to Terminase_1 family (PF03354). Gene 3

11 encodes for a protein with a signal peptide (residues 1-21) and a transmembrane helix (residues 29-

12 51) and is homologous to protein Gp3 of Klebsiella phage PhiKO2. Besides, a prohead maturation

13 protease (Gene 5) belonging to the MEROPS peptidase family S49 (protease IV family) was also

14 identified in phage AS1. It has a conserved catalytic Serine-Lysine dyad typical of a serine protease

15 domain (cd07022). The proteolytic activity is essential for the phage capsid maturation. The major

16 capsid protein of AS1 (Gene 6) belongs to HK97 family and it forms coiled coil structure at amino

17 acid positions 4-34 and 39-59. The delta domain of HK97 major capsid protein was shown to have

18 coiled coils involved in prohead assembly and maturation and it was also found to be removed by

19 proteases after the assembly (Oh et al. 2014). Gene 8 of the assembled genome codes for a protein

20 containing gp6 domain (cd08054) with 36 conserved oligomerization interface amino acid residues of

21 the domain. Gp6 of bacteriophage HK97 encodes head tail connector protein which forms an

22 oligomeric ring and serves as an interface for head and tail attachment (Cardarelli et al. 2010). 

$s p$. N4. It possess a C-terminal conserved domain similar to Shufflon-specific DNA recombinase Rci and bacteriophage Hp1_like integrase (cd00796) belonging to the superfamily of DNA breaking-

4 rejoining enzymes. These enzymes contain a catalytic domain with six conserved amino acid residues. The presence of integrase gene indicates the potential for a temperate lifestyle which is

6 further strengthened by the absence of any tRNA genes in the genome. It can be assumed that phage 7 AS1 utilizes its host's tRNAs for translating the mRNA. Presence of tRNA genes provide phage with 8 competitive advantage over other phages through more efficient expression of their own genes 9 independent of their host's tRNAs. Whereas, their absence results in a narrow host range, making the 10 phage more particular about selecting the host with similar codon usage bias (Bailly-Bechet et al. 11 2007).

Two sequence specific DNA methyl transferase genes, DNA adenine methyltransferase (DAM) and DNA (Cytosine-5) methyltransferase (DCM), present in AS1 genome control DNAprotein interactions by methylating adenine and cytosine residues of the DNA sequence. Considering this fact, phage encoded DNA adenine methyl transferase may be interpreted as a coevolutionary 16 adaptation of the phage to protect itself from the host restriction enzymes (Murphy et al. 2014).

17 Normally, specific DNA methyl transferases are part of host restriction-modification system which 18 methylate host DNA at specific sites. This protects the host DNA from cleavage by its own restriction endonucleases which on the other hand destroy the incoming foreign phage DNA. These enzymes were also reported to have functions like controlling the expression of host virulence genes and 21 selective silencing of genes that they methylate (Low et al. 2001, Oakey et al. 2002). In bacteriophage 22 lambda, methylation by DNA adenine methyltransferase is associated with packaging of the phage 23 genome (Sternberg and Coulby 1990), whereas, DNA (Cytosine-5) - methyltransferases are found 
1 rarely in bacteriophage genomes and their functions in the context of viral lifecycle are unknown.

2 Interestingly, a gene coding for the protein $\mathrm{HNH}$ endonuclease (gene 52) having homology to 5-

3 methylcytosine specific restriction endonuclease McrA family (COG1403) with two highly conserved

4 histidine and one asparagine residues was identified in AS1 genome nearby the lysozyme gene within

5 the lysis module. McrA is a member of the superfamily HNHc (cI00083) which includes many

6 homing endonucleases, bacterial colicins, pyocins etc. and are rarely reported in Podoviruses.

7 Modified cytosine restriction (Mcr) systems capable of restricting phage $\lambda$ modified by sequence

8 specific cytosine methylases has been earlier reported in Escherichia coli strain K12 (Raleigh and

9 Wilson 1986, Raleigh et al. 1989). The protein Gp74 from lambda-like phage HK97 was reported to

10 possess HNH endonuclease activity and mediate the cleavage of phage DNA (Moodley et al. 2012).

11 Later, Kala et al. (2014) discovered that these endonucleases were associated with the DNA

12 packaging terminase proteins in HK97 and majority of the large terminase subunits linked with HNH

13 endonucleases belonged to the Terminase_1 family (PF03354). The position of AS1 HNH

14 endonuclease, adjacent to terminase and other morphogenetic genes, suggests its potential

15 involvement in DNA packaging.

16 Genome of phage AS1 encodes pyocin activator protein (gene 36) with a conserved domain

17 belonging to the PrtN family (PF11112) and is involved in the transcriptional activation of the

18 polypeptide endonuclease toxin, pyocin. Other than lysozyme and HNH endonuclease, the lysis

19 module encodes a Cro/CI family transcriptional regulator containing a HTH motif and a phage anti-

20 termination Q type I family protein. The decision of the phage to enter either lytic or lysogenic cycle

21 is determined by $\mathrm{Cro} / \mathrm{C} 1$ regulatory system which is well characterized and studied in phage $\lambda$

22 infecting the bacterium Escherichia coli (Ptashne 1967, Eisen et al. 1970, Schubert et al. 2007). The

23 antitermination Q Type I protein positively regulates the phage early and late genes by modifying the 
1 host RNA polymerase and making it to proceed transcription past the terminator sequences. A total of

2 nine trans-membrane helices were predicted in seven proteins. 53 promoter sequences and 20 rho-

3 independent terminator sequences were identified in the assembled genome.

$4 \quad$ Phylogenetic analysis revealed a mosaic pattern of inheritance of various proteins encoded by

5 phage AS1 (Fig. 5). Major capsid protein, terminase large subunit and portal protein of AS1 had a

6 Siphoviral lineage, whereas, integrase and major tail proteins were closely related to other Podoviral

7 homologs. Recombination driven exchange of genetic material and the resulting genetic mosaicism is

8 wide-spread among Caudovirales. Even though prominent morphological differences exist between

9 the three families (specifically tail morphology), the differentiation is not clear cut due to striking

10 sequence level similarities among several members of these different families. A well-known

11 example for this is the genetic relatedness between phages lambda and P22 which are, however,

12 classified under Siphoviridae and Podoviridae, respectively, based on their tail morphology. No

13 lineage for the tail proteins of AS1 were deduced due to the limited availability of homologs.

\section{Conclusion} marine bacteria belonging to genus Marinobacter, strain D1S9. The presence of integrase gene, occurrence of DNA methyltransferases and the existence of a significant percentage of phage AS1 genes within various Marinobacter genomes are suggestive of their intense association with the host. From the genome analysis, it is evident that phage AS1 relies greatly on its host's replication and translation machinery. Its codon usage bias must be similar to that of the host, since the phage 21 genome does not encode any tRNA genes. Another striking feature of the genome is its mosaicism

22 evident from the inheritance pattern of some of the important proteins with high similarity to their 23 siphoviral counterparts. It also contains most of the morphogenetic, assembly, and lysis genes 
involved in the lytic induction. AS1 genome also encodes a gene which positively regulates the expression of the bacterial toxin, pyocin; an interaction which attributes competitive advantage to the host. All the above arguments indicate the possible coevolutionary interactions between the host and the virus. As the members of genus Marinobacter are organisms with both phenotypic and metabolic versatility and reported to have many significant ecological functions like their contribution in biogeochemical cycles and marine snow formation, extensive studies on the involvement of these viruses in impacting host metabolism as well as recruitment of this virus to metagenome need to be carried out. The present study is a detailed analysis of the genomic properties of Marinobacter phage AS1, guiding future research on intricate virus-host interactions and the role of phages in the ecological functioning of the genus Marinobacter.

\section{References}

1. Suttle CA (2007) Marine viruses - major players in the global ecosystem. Nat Rev Microbiol 5:801-812.

2. Sime-Ngando T (2014) Environmental bacteriophages: viruses of microbes in aquatic ecosystems. Front Microbiol 5:355.

3. Middelboe M, Lyck PG (2002) Regeneration of dissolved organic matter by viral lysis in marine microbial communities. Aquat Microb Ecol 27:187-194.

4. Bouvier T, Del Giorgio PA (2007) Key role of selective viral-induced mortality in determining marine bacterial community composition. Environ microbiol 9:287-297.

5. McDaniel LD, Young E, Delaney J, Ruhnau F, Ritchie KB, Paul JH (2010) High frequency of horizontal gene transfer in the oceans. Science 330:50.

6. Winget DM, Helton RR, Williamson KE, Bench SR, Williamson SJ, Wommack KE (2011) Repeating patterns of virioplankton production within an estuarine ecosystem. Proc Natl Acad Sci USA 108:11506-11511.

7. Stern A, Sorek R (2011) The phage-host arms race: shaping the evolution of microbes. Bioessays 33:43-51.

8. Xia G, Wolz C (2014) Phages of Staphylococcus aureus and their impact on host evolution. Infection, Genet Evol 21:593-601. 
9. Buckling A, Brockhurst M (2012) Bacteria-virus coevolution. In: Soyer O (ed) Evolutionary systems biology, Springer, New York, NY pp. 347-370.

10. Hall AR, Scanlan PD, Morgan AD, Buckling A (2011) Host-parasite coevolutionary arms races give way to fluctuating selection. Ecol Lett. $2011 \mathrm{Jul} ; 14(7): 635-42$.

11. Gokhale CS, Papkou A, Traulsen A, Schulenburg H (2013) Lotka-Volterra dynamics kills the Red Queen: population size fluctuations and associated stochasticity dramatically change host-parasite coevolution. BMC Evol Biol 13:254.

12. Hendrix RW, Smith MC, Burns RN, Ford ME, Hatfull GF (1999) Evolutionary relationships among diverse bacteriophages and prophages: all the world'sa phage. Proc Natl Acad Sci U S A 96:2192-2197.

13. Hatfull GF, Hendrix RW (2011) Bacteriophages and their genomes. Curr Opin Virol 1:298303.

14. Gauthier MJ, Lafay B, Christen R, Fernandez L, Acquaviva M, Bonin P, Bertrand JC (1992) Marinobacter hydrocarbonoclasticus gen. nov., sp. nov., a new, extremely halotolerant, hydrocarbon-degrading marine bacterium. Int J Syst Evol Microbiol 42:568-576.

15. Martin S, Márquez MC, Sánchez-Porro C, Mellado E, Arahal DR, Ventosa A (2003) Marinobacter lipolyticus sp. nov., a novel moderate halophile with lipolytic activity. Int J Syst Evol Microbiol 53:1383-1387.

16. Yoon JH, Lee MH, Kang SJ, Oh TK (2007) Marinobacter salicampi sp. nov., isolated from a marine solar saltern in Korea. Int J Syst Evol Microbiol 57:2102-2105.

17. Zhang DC, Li HR, Xin YH, Chi ZM, Zhou PJ, Yu Y (2008) Marinobacter psychrophilus sp. nov., a psychrophilic bacterium isolated from the Arctic. Int J Syst Evol Microbiol 58:14631466.

18. Xu XW, Wu YH, Wang CS, Yang JY, Oren A, Wu M (2008) Marinobacter pelagius sp. nov., a moderately halophilic bacterium. Int J Syst Evol Microbiol 58:637-640.

19. Wang CY, Ng CC, Tzeng WS, Shyu YT (2009) Marinobacter szutsaonensis sp. nov., isolated from a solar saltern. Int J Syst Evol Microbiol 59:2605-2609.

20. Wang H, Li H, Shao Z, Liao S, Johnstone L, Rensing C, Wang G (2012) Genome sequence of deep-sea manganese-oxidizing bacterium Marinobacter manganoxydans MnI7-9. J Bacteriol 194:899-900. 
21. Chua MJ, Campen RL, Wahl L, Grzymski JJ, Mikucki JA (2018) Genomic and physiological characterization and description of Marinobacter gelidimuriae sp. nov., a psychrophilic, moderate halophile from Blood Falls, an antarctic subglacial brine. FEMS Microbiol Ecol 94:fiy021.

22. Green DH, Bowman JP, Smith EA, Gutierrez T, Bolch CJ (2006) Marinobacter algicola sp. nov., isolated from laboratory cultures of paralytic shellfish toxin-producing dinoflagellates. Int J Syst Evol Microbiol 56:523-527.

23. Lee OO, Lai PY, Wu HX, Zhou XJ, Miao L, Wang H, Qian PY (2012) Marinobacter xestospongiae sp. nov., isolated from the marine sponge Xestospongia testudinaria collected from the Red Sea. Int J Syst Evol Microbiol 62:1980-1985.

24. Huu NB, Denner EB, Ha DT, Wanner G, Stan-Lotter H (1999) Marinobacter aquaeolei sp. nov., a halophilic bacterium isolated from a Vietnamese oil-producing well. Int J Syst Evol Microbiol 49:367-375.

25. Shieh WY, Jean WD, Lin YT, Tseng M (2003) Marinobacter lutaoensis sp. nov., a thermotolerant marine bacterium isolated from a coastal hot spring in Lutao, Taiwan. Can $\mathbf{J}$ Microbiol 49:244-252.

26. Kaeppel EC, Gärdes A, Seebah S, Grossart HP, Ullrich MS (2012) Marinobacter adhaerens sp. nov., isolated from marine aggregates formed with the diatom Thalassiosira weissflogii. Int J Syst Evol Microbiol 62:124-128.

27. Lupette J, Lami R, Krasovec M, Grimsley N, Moreau H, Piganeau G, Sanchez-Ferandin S ((2016) Marinobacter dominates the bacterial community of the Ostreococcus tauri phycosphere in culture. Front Microbiol 7:1414.

28. Sandhya SV, Preetha K, Vijayan KK (2017) Phylogenetic diversity of culturable bacteria in Chaetoceros gracilis mass culture system of a marine finfish hatchery. J Mar Biol Ass India 59:12-18.

29. Handley KM, Lloyd JR (2013) Biogeochemical implications of the ubiquitous colonization of marine habitats and redox gradients by Marinobacter species. Front Microbiol 4:136.

30. Kaye JZ, Sylvan JB, Edwards KJ, Baross JA (2011) Halomonas and Marinobacter ecotypes from hydrothermal vent, subseafloor and deep-sea environments. FEMS Microbiol Ecol 75:123-133. 
31. Bonis BM, Gralnick JA (2015) Marinobacter subterrani, a genetically tractable neutrophilic Fe (II)-oxidizing strain isolated from the Soudan Iron Mine. Front Microbiol 6:719.

32. Singer E, Webb EA, Nelson WC, Heidelberg JF, Ivanova N, Pati A, Edwards KJ (2011) The genomic potential of Marinobacter aquaeolei- A biogeochemical opportunitroph. Appl Environ Microbiol 77:2763-2771.

33. Zhu M, Wang M, Jiang Y, You S, Zhao G, Liu Y, Yang Q, Liu Q, Liu Z, Gong Z, Shao H (2018) Isolation and Complete Genome Sequence of a Novel Marinobacter Phage B23. Curr microbiol 75:1619-1625.

34. Middelboe M, Chan A, Bertelsen SK (2010) Isolation and life cycle characterization of lytic viruses infecting heterotrophic bacteria and cyanobacteria. In: Wilhelm SW, Weinbauer MG, Suttle CA (ed) Manual of aquatic viral ecology, American Society of Limnology and Oceanography, pp. 118-133.

35. Amann RI, Ludwig W, Schleifer KH (1995) Phylogenetic identification and in situ detection of individual microbial cells without cultivation. Microbiol Mol Biol Rev 59:143-169.

36. Pradeep Ram AS, Arnous B, Danger M, Carrias JF, Lacroix G, Sime-Ngando T (2010) High and differential viral infection rates within bacterial 'morphopopulations' in a shallow sand pit lake (Lac de Créteil, France). FEMS Microbiol Ecol 74:83-92.

37. Lawrence JE, Steward GF (2010) Purification of viruses by centrifugation. In: Wilhelm SW, Weinbauer MG, Suttle CA (ed) Manual of aquatic viral ecology, American Society of Limnology and Oceanography, pp. 166-181.

38. Yang Y, Cai L, Ma R, Xu Y, Tong Y, Huang Y, Jiao N, Zhang R (2017) A novel roseosiphophage isolated from the oligotrophic South China Sea. Viruses 9:109.

39. Andrews S (2010) FastQC: a quality control tool for high throughput sequence data.

40. Bankevich A, Nurk S, Antipov D, Gurevich AA, Dvorkin M, Kulikov AS, Lesin VM, Nikolenko SI, Pham S, Prjibelski AD, Pyshkin AV (2012) SPAdes: a new genome assembly algorithm and its applications to single-cell sequencing. J Comput biol 19:455-477.

41. Aziz RK, Bartels D, Best AA, DeJongh M, Disz T, Edwards RA, Formsma K, Gerdes S, Glass EM, Kubal M, Meyer F (2008) The RAST Server: rapid annotations using subsystems technology. BMC genomics 9:75. 
42. Marchler-Bauer A, Bo Y, Han L, He J, Lanczycki CJ, Lu S, Chitsaz F, Derbyshire MK, Geer RC, Gonzales NR, Gwadz M (2016) CDD/SPARCLE: functional classification of proteins via subfamily domain architectures. Nucleic Acids Res 45:D200-D203.

43. Lowe TM, Chan PP (2016) tRNAscan-SE On-line: integrating search and context for analysis of transfer RNA genes. Nucleic Acids Res 44:W54-W57.

44. Naville M, Ghuillot-Gaudeffroy A, Marchais A, Gautheret D (2011) ARNold: a web tool for the prediction of Rho-independent transcription terminators. RNA Biol 8:11-13.

45. Reese MG (2001) Application of a time-delay neural network to promoter annotation in the Drosophila melanogaster genome. Comput Chem 26:51-56.

46. Kumar S, Stecher G, Tamura K ((2016) MEGA7: molecular evolutionary genetics analysis version 7.0 for bigger datasets. Mol Biol Evol 33:1870-1874.

47. Bradley DE (1967) Ultrastructure of bacteriophage and bacteriocins. Bacteriol Rev 31:230.

48. Oh B, Moyer CL, Hendrix RW, Duda RL (2014) The delta domain of the HK97 major capsid protein is essential for assembly. Virology 456:171-178.

49. Cardarelli L, Lam R, Tuite A, Baker LA, Sadowski PD, Radford DR, Rubinstein JL, Battaile KP, Chirgadze N, Maxwell KL, Davidson AR (2010) The crystal structure of bacteriophage HK97 gp6: defining a large family of head-tail connector proteins. J Mol Biol 395:754-768.

50. Bailly-Bechet M, Vergassola M, Rocha E (2007) Causes for the intriguing presence of tRNAs in phages. Genome Res 17:1486-1495.

51. Murphy J, Klumpp J, Mahony J, O’Connell-Motherway M, Nauta A, van Sinderen D (2014) Methyltransferases acquired by lactococcal 936-type phage provide protection against restriction endonuclease activity. BMC genomics 15:831.

52. Low DA, Weyand NJ, Mahan MJ (2001) Roles of DNA adenine methylation in regulating bacterial gene expression and virulence. Infect Immun 69:7197-7204.

53. Oakey HJ, Cullen BR, Owens L (2002) The complete nucleotide sequence of the Vibrio harveyi bacteriophage VHML. J Appl Microbiol 93:1089-1098.

54. Sternberg N, Coulby J (1990) Cleavage of the bacteriophage P1 packaging site (pac) is regulated by adenine methylation. Proc Natl Acad Sci U S A 87:8070-8074.

55. Raleigh EA, Wilson G (1986) Escherichia coli K-12 restricts DNA containing 5methylcytosine. Proc Natl Acad Sci U S A 83:9070-9074. 
56. Raleigh EA, Trimarchi R, Revel H (1989) Genetic and physical mapping of the mcrA (rglA) and morB (rglB) loci of Escherichia coli K-12. Genetics 122:279-296.

57. Moodley S, Maxwell KL, Kanelis V (2012) The protein gp74 from the bacteriophage HK97 functions as a HNH endonuclease. Protein Sci 21:809-818.

58. Kala S, Cumby N, Sadowski PD, Hyder BZ, Kanelis V, Davidson AR, Maxwell KL (2014) HNH proteins are a widespread component of phage DNA packaging machines. Proc Natl Acad Sci U S A 111:6022-6027.

59. Ptashne M (1967) Specific binding of the $\lambda$ phage repressor to $\lambda$ DNA. Nature 214:232.

60. Eisen H, Brachet P, Da Silva LP, Jacob F (1970) Regulation of repressor expression in $\lambda$. Proc Natl Acad Sci U S A 66:855-862.

61. Schubert RA, Dodd IB, Egan JB, Shearwin KE (2007) Cro's role in the CI-Cro bistable switch is critical for $\lambda$ 's transition from lysogeny to lytic development. Genes Dev 21:24612472. 
Table 1. Genome features of Marinobacter phage AS1

\begin{tabular}{ll}
\hline Feature & Marinobacter phage AS1 \\
\hline Genome size & $36,994 \mathrm{bp}$ \\
GC content & $57 \%$ \\
Total no. of proteins & 52 \\
No. of proteins with putative function & 21 \\
tRNA genes & None \\
Proteins with trans-membrane helices & 7 \\
\hline
\end{tabular}


Table 2. Genome annotation of Marinobacter phage AS1

\begin{tabular}{|c|c|c|c|c|c|c|}
\hline Gene & $\begin{array}{l}\text { Start } \\
\text { (bp) }\end{array}$ & $\begin{array}{l}\text { Stop } \\
\text { (bp) }\end{array}$ & $\begin{array}{l}\text { Length } \\
\text { (bp) }\end{array}$ & Strand & Putative function & E-value \\
\hline 1 & 70 & 531 & 462 & + & $\begin{array}{l}\text { Phage terminase small subunit } \\
\text { P27 family }\end{array}$ & $3.2 \mathrm{E}-111$ \\
\hline 2 & 531 & 2216 & 1686 & + & Terminase large subunit & 0.0 \\
\hline 3 & 2210 & 2404 & 195 & + & Gp3 & $2.8 \mathrm{E}-19$ \\
\hline 4 & 2404 & 3669 & 1266 & + & Putative portal protein & 0.0 \\
\hline 5 & 3657 & 4589 & 933 & + & Serine peptidase & 0.0 \\
\hline 6 & 4663 & 5946 & 1284 & + & Major capsid head protein & 0.0 \\
\hline 7 & 6000 & 6224 & 225 & + & Hypothetical protein & $1.8 \mathrm{E}-48$ \\
\hline 8 & 6262 & 6795 & 534 & + & Gp6 & $6.4 \mathrm{E}-116$ \\
\hline 9 & 6797 & 7348 & 552 & + & Hypothetical protein & 4.5E-128 \\
\hline 10 & 7348 & 7902 & 555 & + & Hypothetical protein & $5.6 \mathrm{E}-127$ \\
\hline 11 & 7899 & 8348 & 450 & + & Hypothetical protein & $6.2 \mathrm{E}-98$ \\
\hline 12 & 8352 & 9107 & 756 & + & Major tail protein & $8.3 \mathrm{E}-8$ \\
\hline 13 & 9172 & 9321 & 150 & + & Hypothetical protein & - \\
\hline 14 & 9385 & 9600 & 216 & + & Hypothetical protein & $1.3 \mathrm{E}-30$ \\
\hline 15 & 9665 & 12883 & 3219 & + & Tail tape measure protein & $2.0 \mathrm{E}-28$ \\
\hline 16 & 12880 & 13278 & 399 & + & Hypothetical protein & $8.3 \mathrm{E}-88$ \\
\hline 17 & 13275 & 14765 & 1491 & + & Tail fiber & $3.1 \mathrm{E}-81$ \\
\hline
\end{tabular}




$\begin{array}{lllllll}18 & 14779 & 16893 & 2115 & + & \text { Tail fiber } & 1.4 \mathrm{E}-125 \\ 19 & 16893 & 18011 & 1119 & + & \text { Hypothetical protein } & 1.1 \mathrm{E}-82 \\ 20 & 18016 & 19926 & 1911 & + & \text { Hypothetical protein } & 0.0 \\ 21 & 19913 & 20146 & 234 & + & \text { Hypothetical protein } & 5.2 \mathrm{E}-56 \\ 22 & 20955 & 20143 & 813 & - & \text { Putative lipoprotein } & 9.2 \mathrm{E}-76 \\ 23 & 21434 & 20979 & 456 & - & \text { Hypothetical protein } & 2.4 \mathrm{E}-96 \\ 24 & 21810 & 22895 & 1086 & + & \text { Integrase } & 0 \\ 25 & 23007 & 23207 & 201 & + & \text { Hypothetical protein } & 4.0 \mathrm{E}-07 \\ 26 & 24260 & 23265 & 996 & - & \text { DNA methyl transferase } & 9.7 \mathrm{E}-131 \\ 27 & 25730 & 24270 & 1461 & - & \text { Hypothetical protein } & -\end{array}$

Table 2. Genome annotation of Marinobacter phage AS1 (continued)

\begin{tabular}{|c|c|c|c|c|c|c|}
\hline 28 & 26213 & 25878 & 336 & - & Hypothetical protein & $2.8 \mathrm{E}-46$ \\
\hline 29 & 26407 & 26210 & 198 & - & Hypothetical protein & $1.3 \mathrm{E}-43$ \\
\hline 30 & 26661 & 26404 & 258 & - & Hypothetical protein & $6.5 \mathrm{E}-57$ \\
\hline 31 & 28046 & 26658 & 1389 & - & $\begin{array}{l}\text { DNA (Cytosine-5)- methyl } \\
\text { transferase } 1\end{array}$ & 0.0 \\
\hline 32 & 28417 & 28043 & 375 & - & Hypothetical protein & 2.7E-27 \\
\hline 33 & 28711 & 28421 & 291 & - & Hypothetical protein & $2.2 \mathrm{E}-37$ \\
\hline 34 & 29094 & 28720 & 375 & - & Hypothetical protein & 3.3E-811 \\
\hline 35 & 29299 & 29105 & 195 & - & Hypothetical protein & $3.5 \mathrm{E}-48$ \\
\hline 36 & 29617 & 29354 & 264 & - & Pyocin activator protein & $3.0 \mathrm{E}-49$ \\
\hline 37 & 29892 & 29614 & 279 & - & $\begin{array}{l}\text { Protein containing phage anti } \\
\text { repressor protein domain }\end{array}$ & $3.2 \mathrm{E}-15$ \\
\hline 38 & 30317 & 29889 & 429 & - & Hypothetical protein & $5.6 \mathrm{E}-81$ \\
\hline 39 & 30981 & 30502 & 480 & - & Hypothetical protein & $1.5 \mathrm{E}-69$ \\
\hline 40 & 31316 & 30978 & 339 & - & Hypothetical protein & $6.5 \mathrm{E}-53$ \\
\hline 41 & 32428 & 31313 & 1116 & - & Hypothetical protein & $5.2 \mathrm{E}-82$ \\
\hline 42 & 32880 & 32473 & 408 & - & Hypothetical protein & $5.1 \mathrm{E}-61$ \\
\hline 43 & 32981 & 33217 & 237 & + & $\begin{array}{l}\text { Cro/cl family transcriptional } \\
\text { regulator }\end{array}$ & $2.0 \mathrm{E}-41$ \\
\hline 44 & 33282 & 34235 & 954 & + & Hypothetical protein & 0.0 \\
\hline 45 & 34285 & 34629 & 345 & + & Hypothetical protein & $1.3 \mathrm{E}-70$ \\
\hline
\end{tabular}




\begin{tabular}{|c|c|c|c|c|c|c|}
\hline 46 & 34619 & 34969 & 351 & + & $\begin{array}{l}\text { Phage anti termination Q type I } \\
\text { family- like protein }\end{array}$ & $1.5 \mathrm{E}-15$ \\
\hline 47 & 35096 & 35527 & 432 & + & Lysozyme & 3.6E-91 \\
\hline 48 & 35524 & 35802 & 279 & + & Hypothetical protein & $5.5 \mathrm{E}-53$ \\
\hline 49 & 35786 & 36016 & 231 & + & Hypothetical protein & $6.0 \mathrm{E}-57$ \\
\hline 50 & 36013 & 36462 & 450 & + & Hypothetical protein & $1.6 \mathrm{E}-43$ \\
\hline 51 & 36464 & 36592 & 129 & + & Hypothetical protein & $2.8 \mathrm{E}-13$ \\
\hline 52 & 36592 & 36975 & 384 & + & HNH endonuclease & 2.3E-87 \\
\hline
\end{tabular}

Table 3. Functional categorization of phage AS1 proteins

\begin{tabular}{lll}
\hline Function & No. & of \\
& proteins & \\
\hline Phage structure and assembly & 13 \\
Phage defense/DNA modification & 2 \\
Transcriptional regulation & 4 \\
Host lysis & 1 \\
Phage integration & 1 \\
Hypothetical proteins & 31 \\
\hline
\end{tabular}




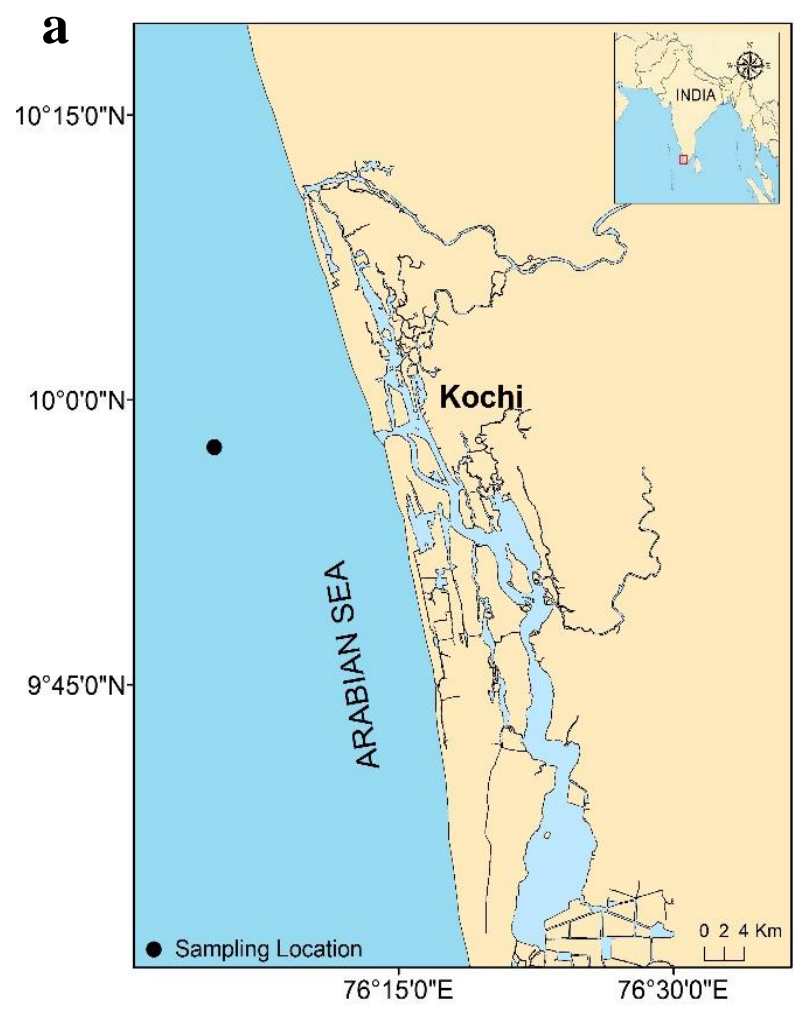

b

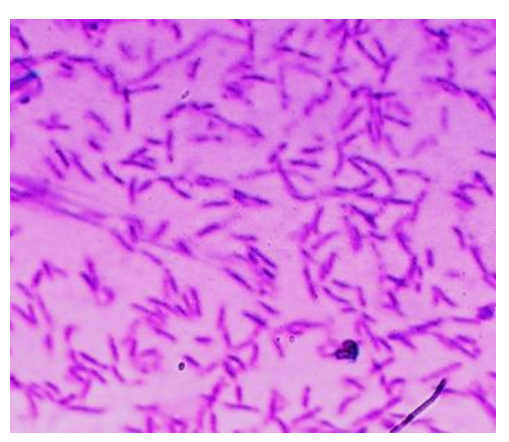

c

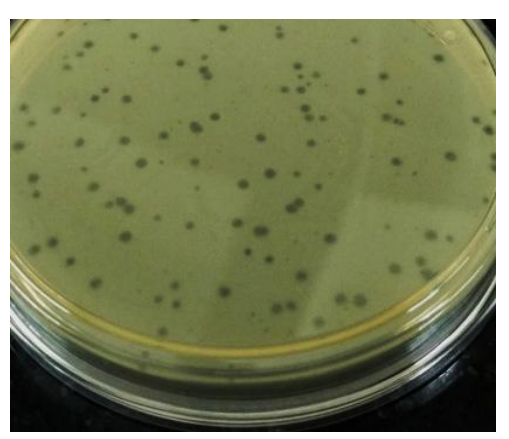

Fig. 1 Isolation of phage AS1. (a) Sampling location in the Arabian Sea, (b) rod shaped Marinobacter host cells after staining with crystal violet, (c) clear round plaques of phage AS1 formed on a lawn of host 


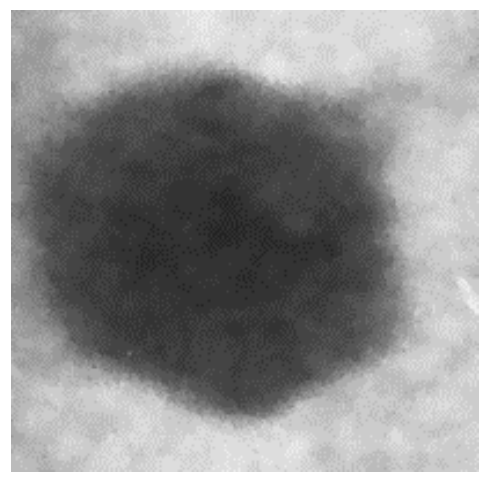

Fig. 2 Morphology of the isolated phage. Electron micrograph of phage AS1. Scale bar equals $50 \mathrm{~nm}$. 


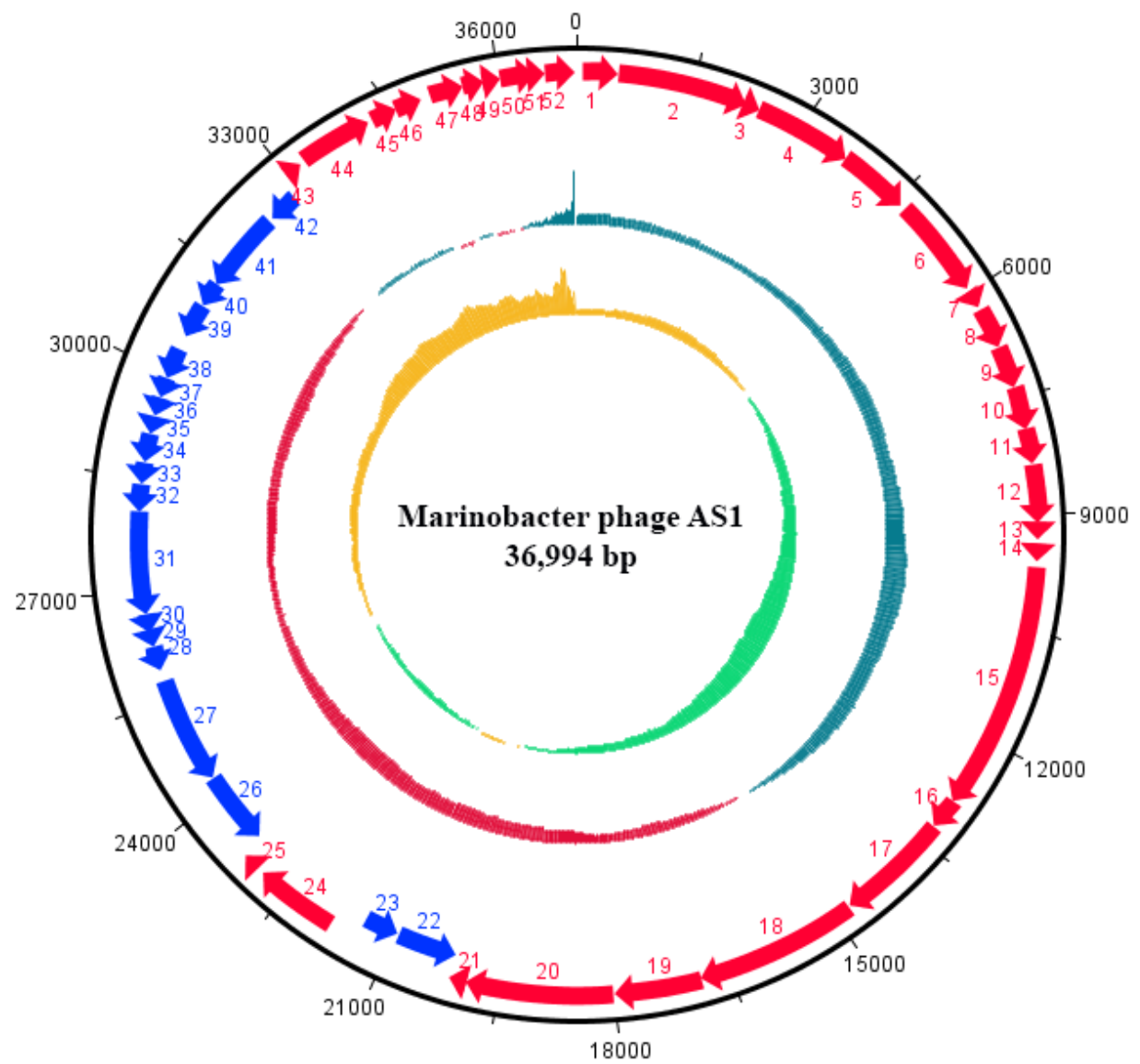

Fig. 3 Circular representation of the double stranded linear genome of Marinobacter phage AS1 featuring (from outside to inside) coding DNA sequences with predicted functions in the forward strand (red), reverse strand (neon blue), GC content (maroon \& blue) and GC skew (green \& yellow). 

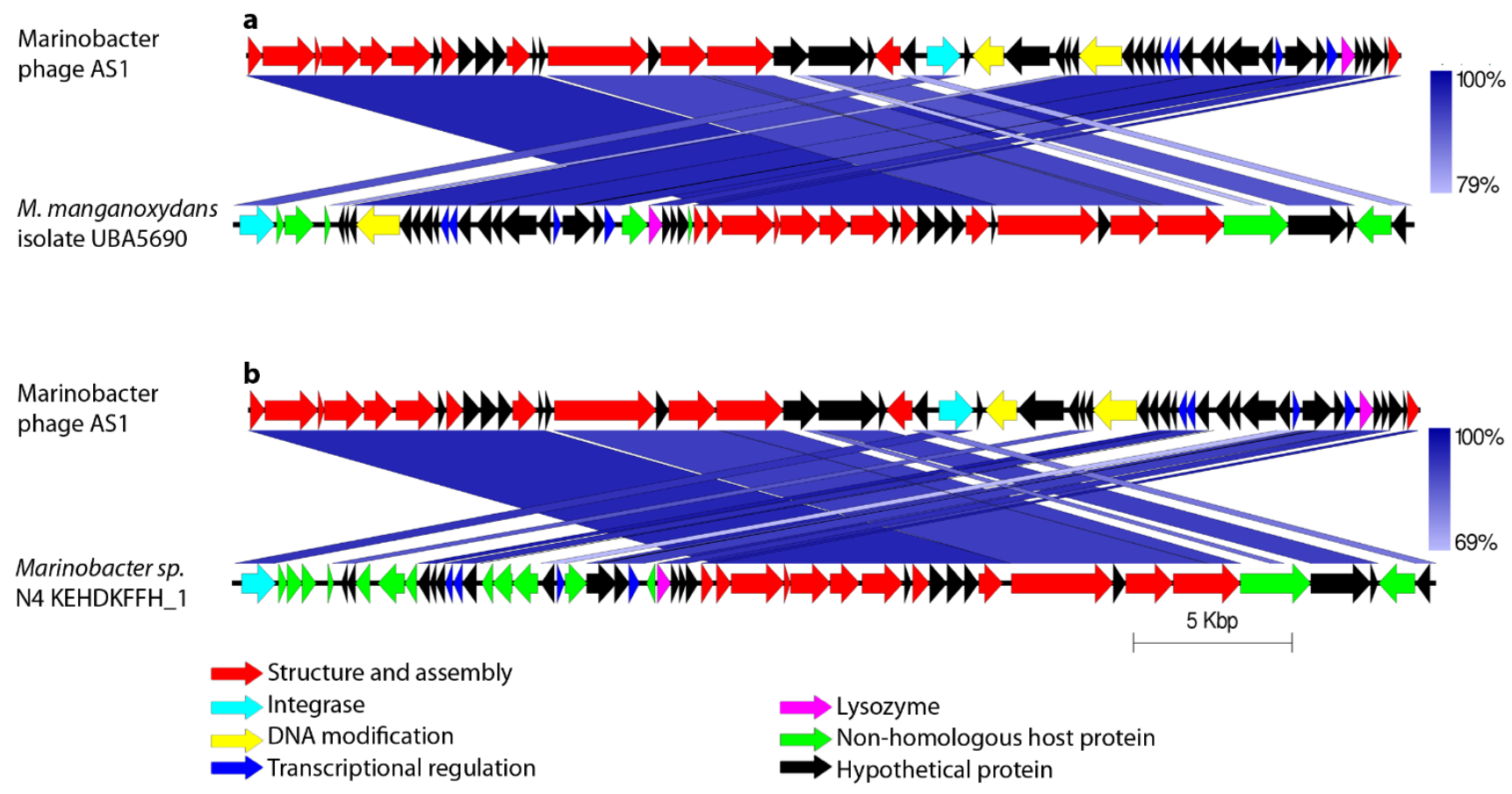

Fig. 4 Comparison of similar sequences found within the sequences of host genus. Comparison with (a) M. manganoxydans isolate UBA5690 and (b) Marinobacter sp. N4 KEHDKFFH_1. The intensity of blue colour indicates the percentage of similarity between the two sequences. 


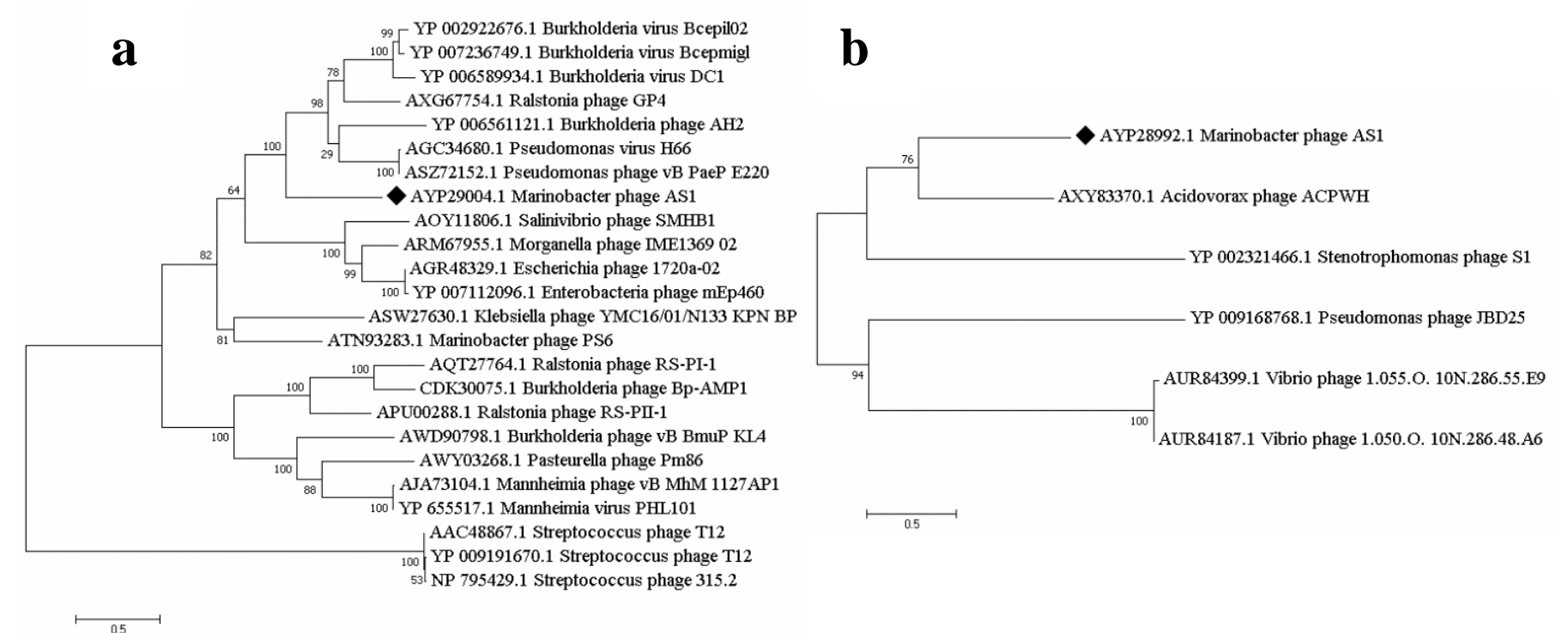

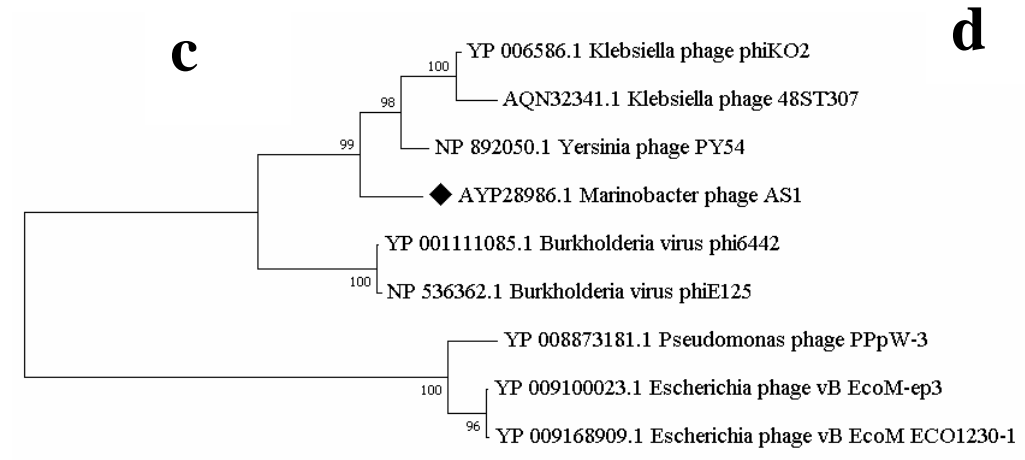
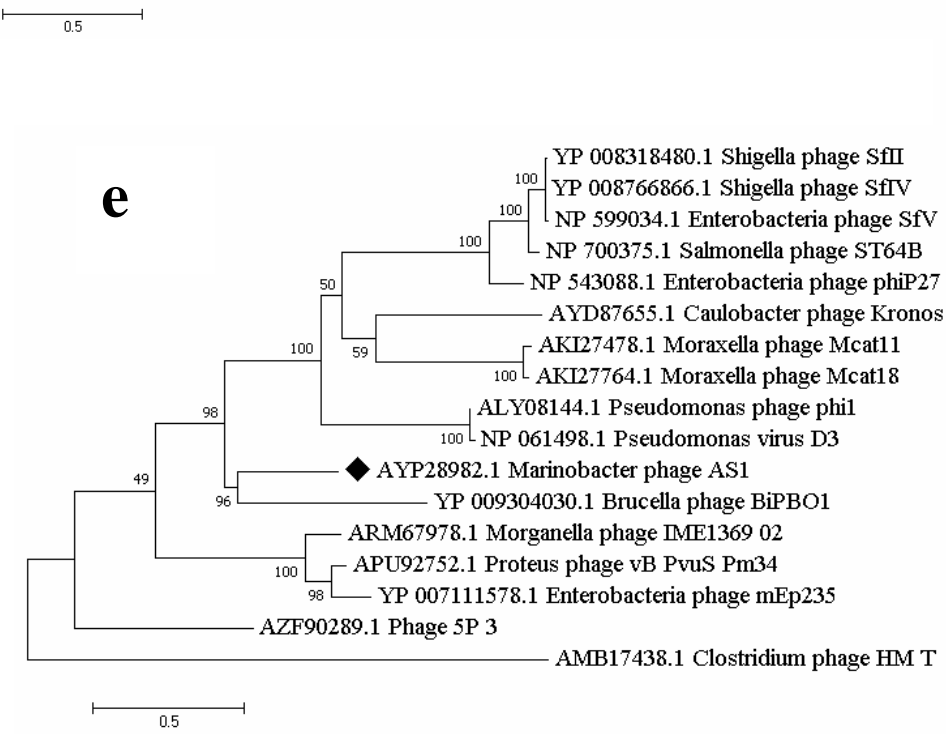

Fig. 5 Phylogenetic trees of AS1 proteins. (a) Integrase, (b) major tail protein, (c) major capsid protein, (d) portal protein and (e) terminase, large subunit.

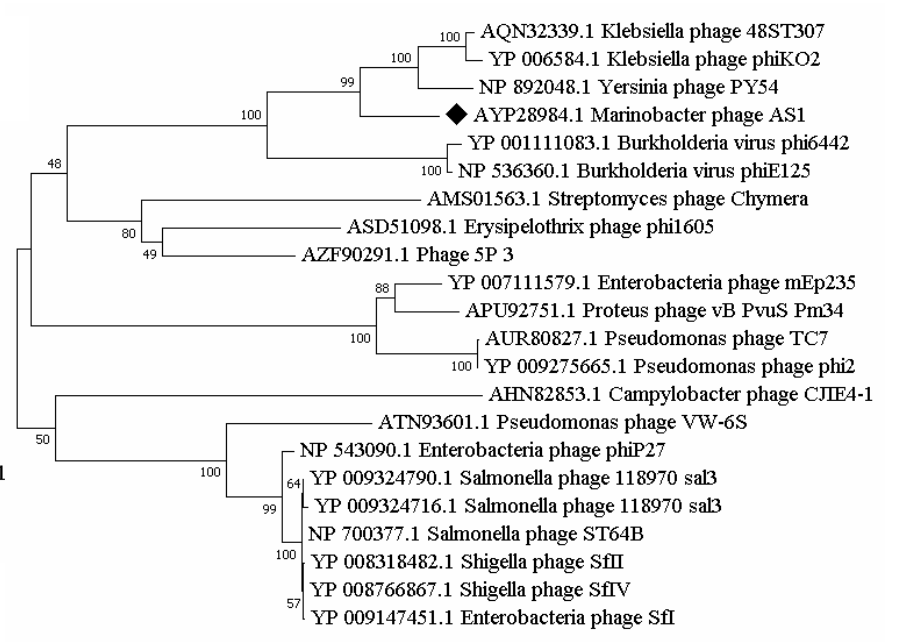

